\title{
Synthesis and Rheological Property of Calcium Aluminate Cement Containing $\mathrm{MgAl}_{2} \mathrm{O}_{4}$ Spinel
}

\author{
FU Yun-Fei, ZHU Bo-Quan, LI Xiang-Cheng, CHEN Ping-An
}

(The State Key Laboratory of Refractories and Metallurgy, Wuhan University of Science and Technology, Wuhan 430081, China)

\begin{abstract}
Calcium aluminate cements with different $\mathrm{MgAl}_{2} \mathrm{O}_{4}$ spinel (CMA) contents and particle sizes were synthesized. The results revealed that when the synthesis temperature was raised from $1400^{\circ} \mathrm{C}$ to $1500^{\circ} \mathrm{C}$, the particle size of $\mathrm{MgAl}_{2} \mathrm{O}_{4}$ (MA) increased from $5 \mu \mathrm{m}$ to $15 \mu \mathrm{m}$. The MA particles appeared in clusters and were distributed around the $\mathrm{CaAl}_{2} \mathrm{O}_{4} / \mathrm{CaAl}_{4} \mathrm{O}_{7}\left(\mathrm{CA} / \mathrm{CA}_{2}\right)$ particles for $\mathrm{CMA}$ synthesized at $1400^{\circ} \mathrm{C}$, while $\mathrm{MA}$ particles were inserted in the $\mathrm{CA} / \mathrm{CA}_{2}$ particles for $\mathrm{CMA}$ synthesized at $1500^{\circ} \mathrm{C}$. At the same time, the setting time lengthened and the viscosity decreased with the increase in MA content and particle size for CMA. The corresponding minimum values of storage modulus and flow point were $0.15 \mathrm{MPa}$ and $4.44 \%$, respectively. It is believed that the higher content of the MA phase and the larger particle size of $\mathrm{CA} / \mathrm{CA}_{2}$ particles in CMA cement can result in a weak flocculation structure in hydrates.
\end{abstract}

Key words: calcium aluminate cement; $\mathrm{MgAl}_{2} \mathrm{O}_{4}$ spinel; synthesis; rheological properties

Because of their excellent corrosion and thermal shock resistance, refractory castables containing $\mathrm{MgAl}_{2} \mathrm{O}_{4}$ spinel are widely used in the high-temperature field such as ladle linings, ladle bottom impact area, and purging plug systems ${ }^{[1-3]}$. The constituents of $\mathrm{MgAl}_{2} \mathrm{O}_{4}$ spinel in refractory castables can effectively absorb the divalent ions of $\mathrm{Fe}^{2+} / \mathrm{Mn}^{3+}$ in molten slags to form a solid solution and consequently increase the viscosity of slag. Thus, slag penetration resistance can be improved significantly. Currently, there are two ways to incorporate the spinel phase into castables, including mixing preformed MA powders with cement and the in situ formation MA phase in cement forming calcium aluminate cement with $\mathrm{MgAl}_{2} \mathrm{O}_{4}$ spinel $(\mathrm{CMA})^{[4]}$. However, mechanical mixing methods can hardly achieve a homogeneous mixture in the microcosmic aspect, and the inhomogeneous parts easily form corroded areas in the bonding phase position. Therefore, CMA cement is developed to avoid this problem. Numerous researchers have prepared CMA cement and tested its properties $^{[5-9]}$. Xiao $^{[10]}$ found that CMA cement can significantly improve corrosion resistance due to the introduction of MA spinel, which had a high melting point and prevented slag from penetrating. Gehre ${ }^{[11]}$ also revealed that corundum $\mathrm{MgAl}_{2} \mathrm{O}_{4}$-spinel based castables had hightemperature mechanical properties and thermal shock resistance when $6 \mathrm{wt} \%$ of CMA cement was used as a binder.
Nevertheless, most researchers have focused on the preparation process of CMA cement and its properties as a castable binder ${ }^{[12-17]}$, and little attention has been concentrated on the rheological properties of CMA cement which will determine the workability of castables. It is also believed that a good knowledge of the rheological properties of CMA cement will be helpful in improving the properties of cement-bonded castables ${ }^{[18-19]}$.

Sliva ${ }^{[20]}$ studied the effect of particle size distribution on the rheological properties of self-flow castables and found that the fluid model transformed from Bingham to Herschel-Bulkley as the ratio of coarse particles increased. Oliveira $^{[21]}$ found that dispersants substantially influenced the rheological properties and setting time, and eventually affected the mechanical strength of castables. Wang ${ }^{[22]}$ further revealed that the dispersants changed the $\mathrm{Ca}^{2+}$ concentration and cement hydration morphologies to affect the properties of refractory castables. Although many researchers focused on the external factors affecting the rheological properties of CMA cement, only a few paid attention to the effect of internal factors such as particle sizes and phase contents on the rheological properties of CMA cement.

Therefore, the aim of this work is to investigate the effect of phase contents and particle size on the microstructures and rheological properties of CMA cement. Different MA contents and particle sizes of CMA cement were fab- 
ricated, and the phase distribution between $\mathrm{MA}$ and $\mathrm{CA} / \mathrm{CA}_{2}$ in CMA cement is also analyzed in detail. The setting time and rheological properties of slurries, such as static state flow and dynamic state flow, are measured to explore the relationship between the microstructures and rheological properties.

\section{Experimental}

Industrial alumina $\left(98.5 \mathrm{wt} \% \mathrm{Al}_{2} \mathrm{O}_{3}\right.$ and $\left.d_{50}=14 \mu \mathrm{m}\right)$, light burned magnesia $\left(83.9 \mathrm{wt} \% \mathrm{MgO}\right.$ and $\left.d_{50}=88 \mu \mathrm{m}\right)$ and calcium carbonate $\left(99.3 \mathrm{wt} \% \mathrm{CaCO}_{3}\right.$ and $\left.d_{50}=10 \mu \mathrm{m}\right)$ were used as raw materials. The mass ratio of raw materials and mineral phase compositions of CMA were designed and are shown in Table 1, wherein the chemical compositions of designed cement samples are located in the sub-triangle of $\mathrm{CaAl}_{2} \mathrm{O}_{4}-\mathrm{CaAl}_{4} \mathrm{O}_{7}-\mathrm{MgAl}_{2} \mathrm{O}_{4}$ at the $\mathrm{Al}_{2} \mathrm{O}_{3}-\mathrm{MgO}-\mathrm{CaO}$ ternary phase diagram ${ }^{[23-24]}$. The raw materials were ball-milled in water media for $3 \mathrm{~h}$ to obtain a homogeneous mixture. After drying at $110^{\circ} \mathrm{C}$, the mixed powders were calcined at $1400^{\circ} \mathrm{C}$ and $1500^{\circ} \mathrm{C}$ with a soaking time of $3 \mathrm{~h}$. Finally, the calcined powders were ground to a suitable fineness, and the specific surface area measured by BET was greater than $0.3 \mathrm{~m}^{2} / \mathrm{g}$.

The phase compositions and morphology characteristics of prepared CMA cement samples were determined by $\mathrm{X}$-ray diffraction (XRD; $\chi$ 'Pert pro) and scanning electron microscopy (SEM; Nova NanoSem 400). The setting time of cement paste was measured according to $\mathrm{GB} / \mathrm{T}$ 1346-2011, in which the penetrated depth of the Vicat equipment needle was recorded.

Slurries used to conduct the rheological experiments were prepared as follows: tabular alumina $(98.9 \mathrm{wt} \%$ $\mathrm{Al}_{2} \mathrm{O}_{3}$; Zhejiang Zili Co. Ltd., China) of various particle sizes $(<0.088 \mathrm{~mm}$ and $0-1 \mathrm{~mm})$, reactive alumina (99.23wt $\% \mathrm{Al}_{2} \mathrm{O}_{3}, d_{50}=4.1 \mu \mathrm{m}$; Zhejiang Zili Co. Ltd., China) and prepared CMA cement. Rheological tests were carried out under the static state flow and dynamic state flow conditions. A rheometer (MCR301; Parr Physica, Austria) with a coaxial cylinder geometry (ST22-4V-40 system) was used, and the testing tempera- ture was set at $25^{\circ} \mathrm{C}$. Under the static state flow test, the shear rate range was between $0.1 \mathrm{~s}^{-1}$ and $500 \mathrm{~s}^{-1}$. Strain was increased from $0.01 \%$ to $500 \%$ logarithmically, and $10 \mathrm{rad} / \mathrm{s}$ natural angular frequency was used for the amplitude sweep test.

\section{Results and discussion}

\subsection{Phase compositions and microstructures of CMA cement}

The XRD patterns of CMA cement synthesized at different temperatures are depicted in Fig. 1 and Fig. 2. Although the main phases are MA, CA and $\mathrm{CA}_{2}$ in all samples, the diffraction peaks of MA phase become stronger as MA contents increase from $63 \mathrm{wt} \%$ to $73 \mathrm{wt} \%$ at the same temperature according to enlargement of the main peak in Fig. 1. Meanwhile, compared with the synthesis temperature at $1400^{\circ} \mathrm{C}$ in Fig. 2, the MA phase diffraction peaks slightly enhanced at $1500^{\circ} \mathrm{C}$ because rising temperature accelerates the synthesis reactions of spinel and promotes the particle growth of MA particles.

The morphologies of different CMA samples are presented in Fig. 3. Figure 3(a,b) indicates that the CA phases in the sample calcined at $1400^{\circ} \mathrm{C}$ show a tabular morphology; the MA phases' shape is granular without octahedral morphology. The MA particles are in clusters and are distributed around the CA particles. When the synthesis temperature is raised to $1500^{\circ} \mathrm{C}$, the tabular phases of CA are observed to grow up to $3-5 \mu \mathrm{m}$, and the particle size of MA phases is between $1 \mu \mathrm{m}$ and $2 \mu \mathrm{m}$ (Fig. 3(c), (d)). Their particle size increased about 3 times. At the same time, MA phases are in octahedral form and are homogeneously distributed among CA particles.

As synthesis temperature is increased from $1400^{\circ} \mathrm{C}$ to $1500^{\circ} \mathrm{C}$, the microstructures of cement samples are different for the same composition of cement in Fig. 3 (a, c) and (b, d), respectively. This indicates that, besides the particles' growth, the phase distribution of $\mathrm{CA} / \mathrm{CA}_{2}$ and $\mathrm{MA}$ also changes dramatically. When the synthesis temperature is $1400^{\circ} \mathrm{C}, \mathrm{MA}$ particles are in clusters in the cement, and MA and $\mathrm{CA} / \mathrm{CA}_{2}$ particles are almost separated loosely.

Table 1 Chemical and mineral phase compositions of CMA cements

\begin{tabular}{|c|c|c|c|c|c|c|c|}
\hline \multirow{2}{*}{ Sample No. } & \multirow{2}{*}{ Synthesis temperature } & \multicolumn{3}{|c|}{ Constituent of raw materials $/ w t \%$} & \multicolumn{3}{|c|}{$\begin{array}{l}\text { Designed phase composition of the ce- } \\
\text { ment } / \text { wt } \%\end{array}$} \\
\hline & & $\begin{array}{c}\text { Industrial } \\
\text { alumina }\end{array}$ & $\begin{array}{l}\text { Calcined } \\
\text { magnesia }\end{array}$ & $\begin{array}{l}\text { Calcium } \\
\text { carbonate }\end{array}$ & MA & $\mathrm{CA}$ & $\mathrm{CA}_{2}$ \\
\hline A & \multirow{2}{*}{$1400^{\circ} \mathrm{C}$} & 63.1 & 15.9 & 21.0 & 63.3 & 33.8 & 2.9 \\
\hline $\mathrm{B}$ & & 65.5 & 20.0 & 14.5 & 73.0 & 23.5 & 3.5 \\
\hline $\mathrm{C}$ & \multirow{2}{*}{$1500^{\circ} \mathrm{C}$} & 63.1 & 15.9 & 21.0 & 63.3 & 33.8 & 2.9 \\
\hline $\mathrm{D}$ & & 65.5 & 20.0 & 14.5 & 73.0 & 23.5 & 3.5 \\
\hline
\end{tabular}

Note: $\mathrm{MA}-\mathrm{MgAl}_{2} \mathrm{O}_{4}, \mathrm{CA}-\mathrm{CaAl}_{2} \mathrm{O}_{4}, \mathrm{CA}_{2}-\mathrm{CaAl}_{4} \mathrm{O}_{7}$. 

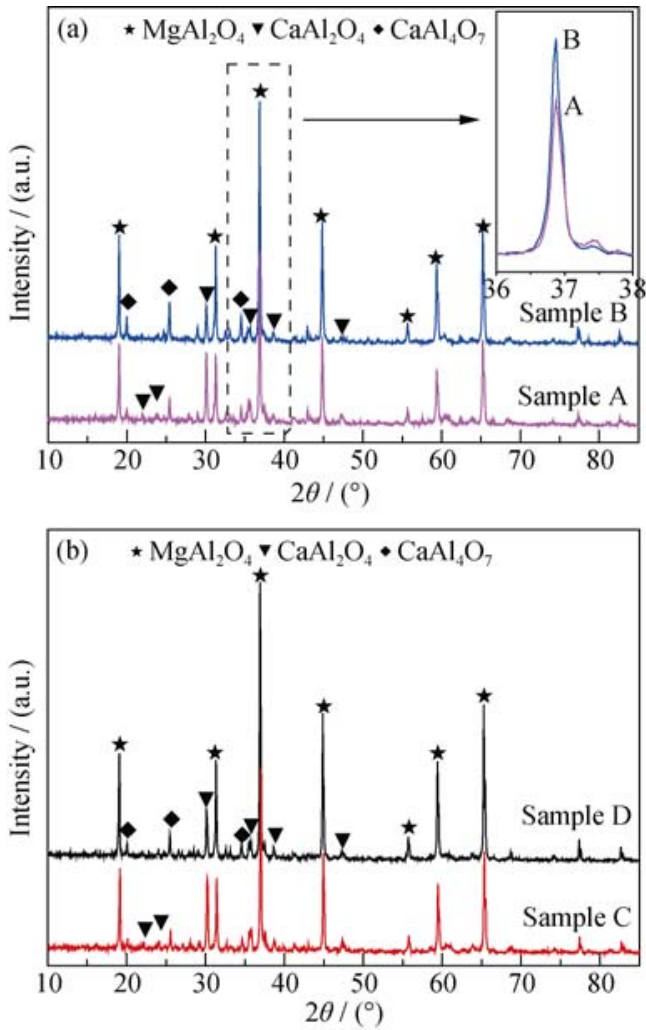

Fig. 1 XRD patterns of CMA cements synthesized at $1400^{\circ} \mathrm{C}$ (a) (samples A and B) and $1500^{\circ} \mathrm{C}$ (b) (samples C and D)
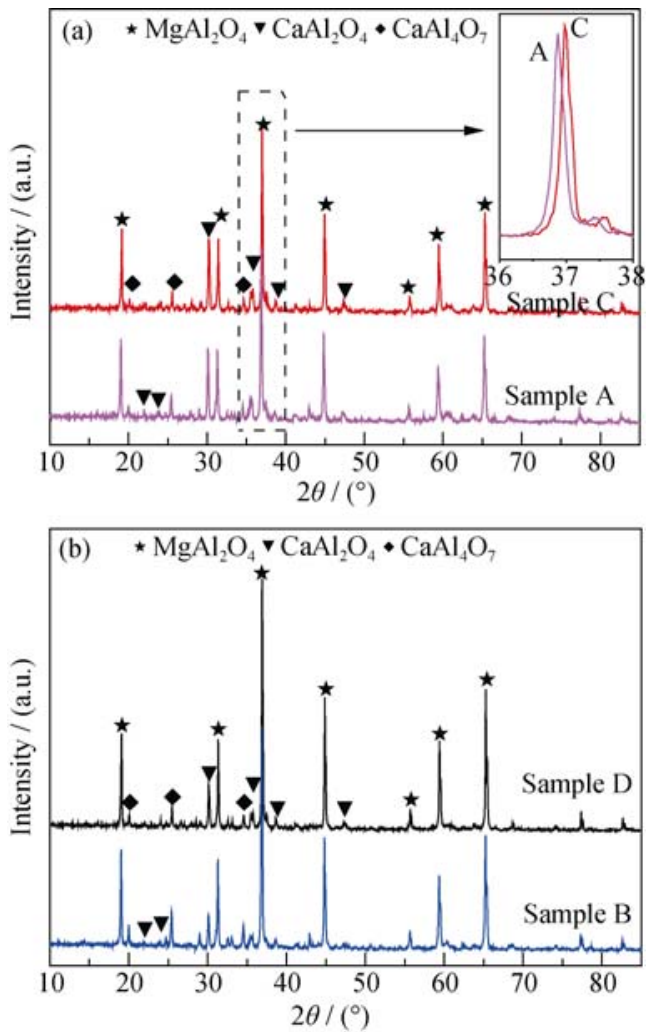

Fig. 2 XRD patterns of CMA cements containing $63 \mathrm{wt} \%$ (a) (samples A and C) and 73wt\% (b) (samples B and D)

However, as the temperature rises to $1500{ }^{\circ} \mathrm{C}$, MA particles are distributed homogeneously and alternately with $\mathrm{CA} / \mathrm{CA}_{2}$ particles. This phenomenon suggests that rising temperature effectively promote the diffusion of $\mathrm{Mg}^{2+} / \mathrm{Al}^{3+}$ or $\mathrm{Al}^{3+} / \mathrm{Ca}^{2+}$. The nucleation and crystal growth process is the main reaction at the initial stage and then transforms into a diffusion-controlled process. Owing to the different ion diffusion rates, the distribution of $\mathrm{MA} / \mathrm{CA}$ phases is also changed.

\subsection{Analysis of the setting time of CMA cement}

Figure 4 presents the setting time of different CMA cements. It shows that the setting time increases with MA contents and particle size increasing. The cement sample A has the shortest setting time with initial setting time of $55 \mathrm{~min}$ and final setting time of $185 \mathrm{~min}$. In comparison, cement sample D has the longest setting time with initial and final setting times of $195 \mathrm{~min}$ and $340 \mathrm{~min}$, respectively. The difference in setting time for CMA cement samples can be attributed to the different hydration processes of calcium aluminate cements. The CA phase is the main hydration material, while the MA phase does not hydrate in CMA cement ${ }^{[25]}$. Thus, cement samples containing more CA hydrate faster, leading to a shorter setting time. In addition, the particle size and content of CA particles also have a strong effect on the setting time of CMA cement. As shown in Fig. 3, when synthesis temperature increases from $1400^{\circ} \mathrm{C}$ to $1500^{\circ} \mathrm{C}$, the particle size of CA phase increases from $3 \mu \mathrm{m}$ to $8 \mu \mathrm{m}$, which leads to a decrease in hydration activity. Thus, the hydration process is inhibited and the setting time of CMA cement is extended. On the other hand, the distribution condition of MA and CA particles can strongly affect the hydration process of CMA cement ${ }^{[21]}$. In Fig. 3(b, d), MA particles around CA particles would hinder the water from penetrating into the inside of cement particles that can react with CA. This will lead to a difficult hydration and result in a longer setting time. In contrast, MA and CA particles present alternative distribution features in Fig. 3(a, c). There are some defects in the CA particles because they cannot form perfect or large particles. Thus, CA can fully contact with water, which leads to faster hydration.

\subsection{Rheological performances of CMA cement slurries}

Figure 5 shows the static rheological curves of slurries for different CMA cement samples. It can be observed that all cement sample slurries show shear thinning behavior in the measured shear rate region. The shear stress increases rapidly as the shear rate increases from 0 to $1 \mathrm{~s}^{-1}$. As the shear rate continuously increases from $1 \mathrm{~s}^{-1}$ to $10 \mathrm{~s}^{-1}$, the shear stress decreases drastically, and the yield stress is obtained in this range. However, as the shear rate increases to higher than $10 \mathrm{~s}^{-1}$, the shear stress increases linearly with the shear rate. 

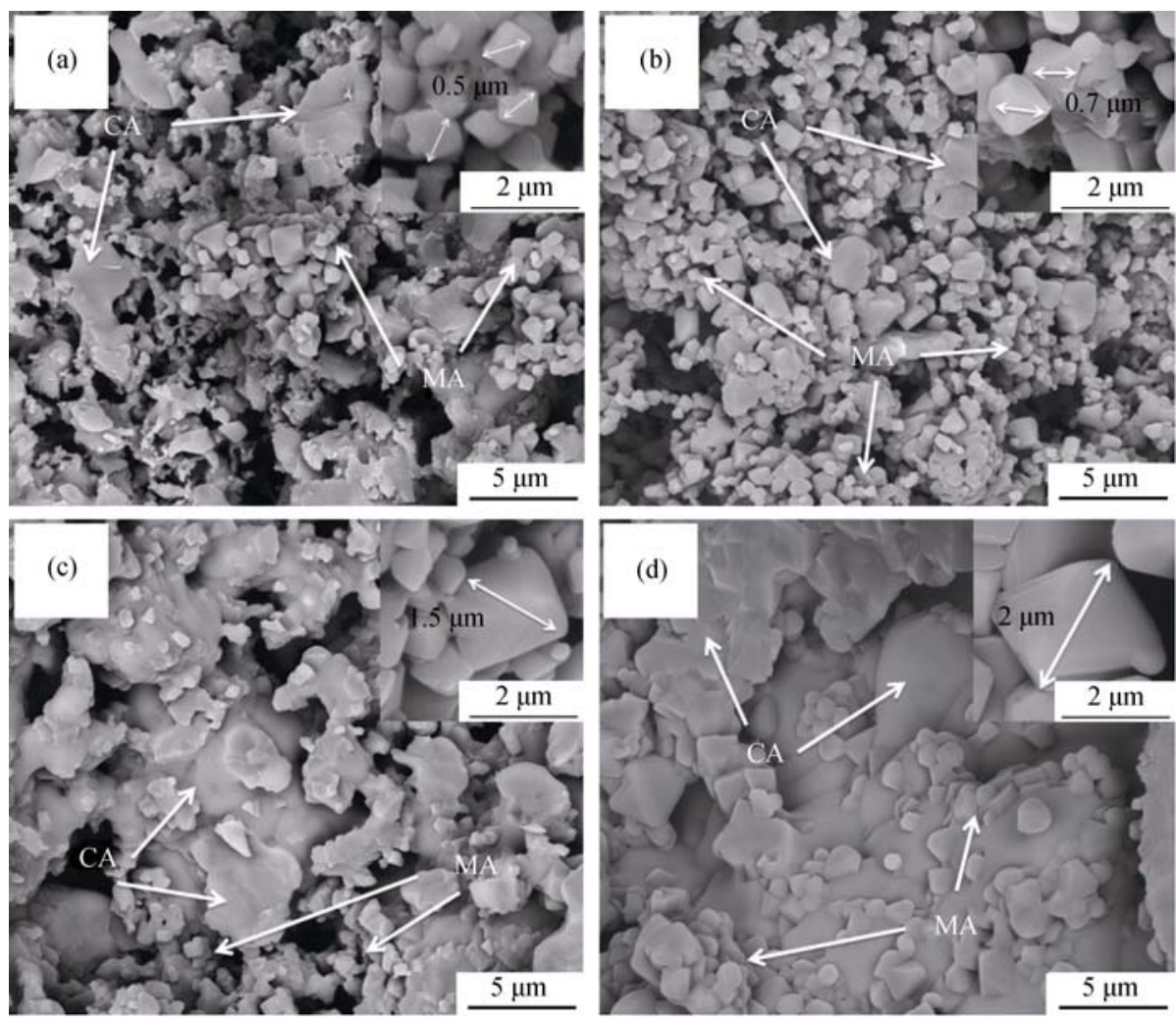

Fig. 3 SEM micrographs of CMA cement samples A, B, C and D (a-d)

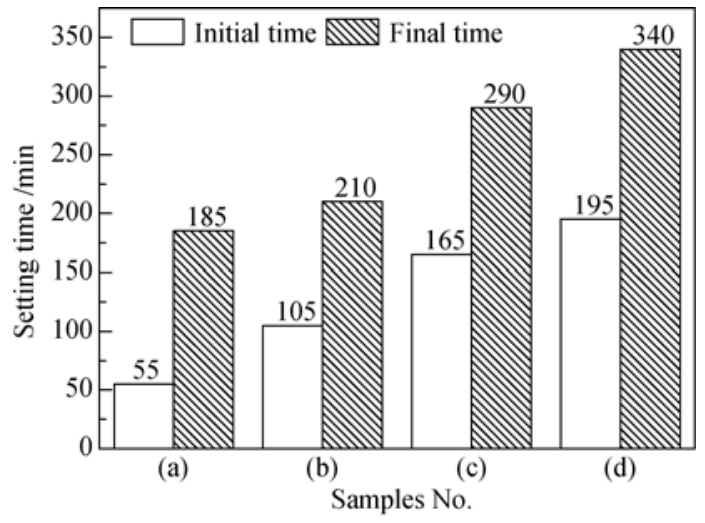

Fig. 4 Setting time of different CMA cements

(a) Mortar for CMA cement A; (b) Mortar for CMA cement B; (c) Mortar for CMA cement C; (d) Mortar for CMA cement D

When CMA cement contacts with water, $\mathrm{CA} / \mathrm{CA}_{2}$ starts to hydrate, forming a flocculation structure, so the shear stress increases rapidly as the shear rate increases from 0 to $1 \mathrm{~s}^{-1}$. When the shear rate is higher than $1 \mathrm{~s}^{-1}$, the flocculation structure of hydration phases starts getting destroyed due to the rotor rotation. Thus, the shear stress decreases quickly as the shear rate increases from $1 \mathrm{~s}^{-1}$ to $10 \mathrm{~s}^{-1}$. However, by the time the shear rate is higher than $10 \mathrm{~s}^{-1}$, the flocculation structure of hydration phases is almost fully destroyed and the fluid becomes a kind of Newton fluid ${ }^{[26]}$, so the shear stress increases linearly with the shear rate. The fitting equations of the shear rate-shear stress curves at the stage of Newton fluid are as follows:

Slurry for CMA cement A: $\tau=0.89 \gamma+365.8$

Slurry for CMA cement B: $\tau=1.00 \gamma+257.9$

Slurry for CMA cement C: $\tau=0.46 \gamma+210.4$

Slurry for CMA cement D: $\tau=0.78 \gamma+115.1$

These fitting results indicate that the four slurries are well fitted with plastic flow and belong to Bingham fluid, in which the relationship between shear rate and shear stress is linear ${ }^{[27]}$.

Figure 5 also shows that shear stress decreases with MA content and particle size increasing, and the slurry with CMA cement containing $63 \mathrm{wt} \%$ MA exhibits the largest yield stress of $365.8 \mathrm{~Pa}$. According to Fig. 3 and Fig. 4 , the particle size of the CA phase is about $3 \mu \mathrm{m}$ and the setting time is the shortest, indicating that the hydration degree of CMA cement A is the largest. Thus, the remaining free water after hydration in slurry $\mathrm{A}$ is the least, and consequently the resistance produced on surface of particles is the largest ${ }^{[25]}$, resulting in maximum shear stress at the same shear rate. With MA contents increasing to $73 \mathrm{wt} \%$, the quantity of CA particles participating in the hydration reaction reduces. Thus, under the same shear rate, the shear stresses of slurries with $73 \mathrm{wt} \%$ MA decrease due to the increase in the remaining free water in slurries. Similarly, CMA cement sample D contains the least CA particles with larger particle size and low hydration activity; therefore, there is a higher amount of remaining free water after the hydration reaction. Thus, the 


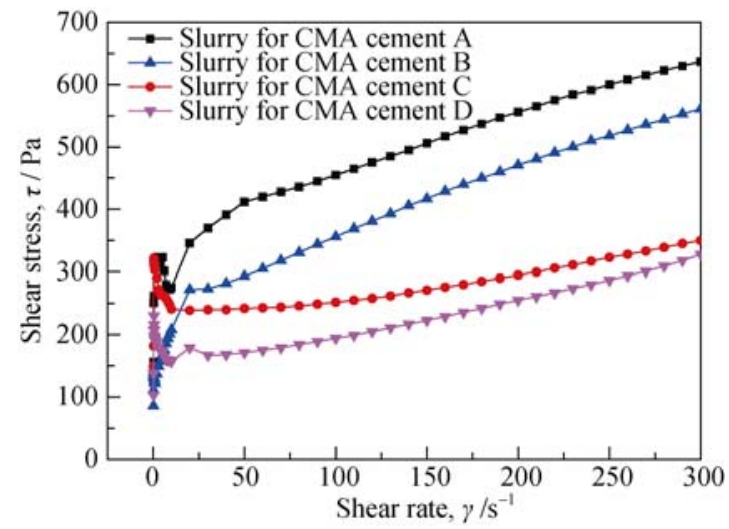

Fig. 5 Shear rate-shear stress curves of CMA cements

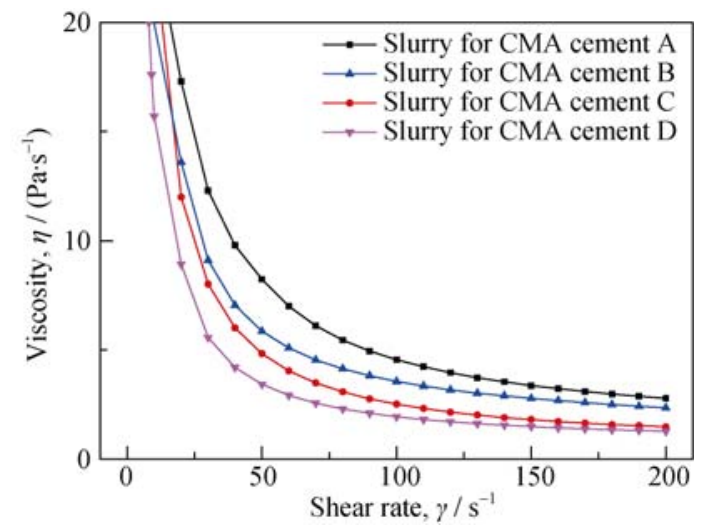

Fig. 6 Viscosity-shear rate curves of CMA cements

slurries show the minimum yield stress and the lowest shear stress.

Figure 6 displays the viscosity-shear rate curves. It can be seen that the apparent viscosities of these four slurries decrease rapidly with the increase in shear rate, and they tend to be stable finally. It can be seen that the apparent viscosity decreases with MA content and particle size increasing. When the shear rate reaches $200 \mathrm{~s}^{-1}$, the slurries with $63 \mathrm{wt} \% \mathrm{MA}$ (synthesized at $1400^{\circ} \mathrm{C}$ ) and with $73 \mathrm{wt} \%$ MA (synthesized at $1500^{\circ} \mathrm{C}$ ) resulted in the highest and lowest viscosity values of $5 \mathrm{~Pa} \cdot \mathrm{s}$ and $2 \mathrm{~Pa} \cdot \mathrm{s}$, respectively. The change trend of viscosity indicates that the apparent viscosity is strongly affected by the phase compositions and particle size. It is well known that flocculated structures formed in slurries are the fundamental factor that has a great influence on the apparent viscosity. Finer CA particles in CMA cement sample A promote the hydration process and formation of flocculation structure, so there is small amount of remaining free water in slurries and this leads to a higher resistance for the rotor ${ }^{[21]}$. Therefore, it shows the highest viscosity among the four slurries.

Although static state flow tests can detect the viscosity and suggest the shear thinning behavior of slurries, they cannot provide sufficient information about CMA slurries. In this case, more detailed information would be obtained via dynamic oscillatory shear measurements in the following tests. Figure 7 shows the amplitude sweeps of these four CMA cement samples. Although the shapes of the curves are consistent approximately, the yield points and flow points are different. When strain is less than $0.02 \%$, the flocculated structures in the slurries are integrated. Therefore, the storage modulus $\left(G^{\prime}\right)$ is almost constant. When strain exceeds $0.03 \%$, the storage moduli begin to decline rapidly, suggesting that the flocculated structure is partly destroyed and slurries belong to viscoelastic solid at this stage. However, slurries begin to flow as the strain increases to the flow point. At this stage, slurries have been transformed from a viscoelastic solid to viscoelastic liquid, and it is in the gel state at the flow point ${ }^{[27]}$.

The corresponding strain of yield points and flow points is also found in Fig. 7. It can be seen that both storage modulus and flow point decrease with increasing MA content and particle size. The storage modulus and flow point for sample A reach the maximum values of $0.84 \mathrm{MPa}$ and $48.55 \%$, respectively. In the range of linear viscoelastic (LVE), storage modulus is strongly affected by the content and particle size of the CA phase ${ }^{[18]}$. Yield points and flow points can reflect the flocculation structural strength in slurry, where a stronger flocculated structure leads to a higher yield stress and viscosity ${ }^{[28]}$. Based on the X-ray patterns and SEM morphologies, the higher content and smaller particle size of the CA phase in CMA cement sample A led to a stronger flocculation structure during the hydration process. Thus, the flow point of slurry exhibited in Fig. 7(a) lagged behind significantly from the three other slurries. With CA content reducing and particle size increasing in CMA cement, the strength of the flocculation structure of hydration decreases, resulting in a decrease in both yield points and flow points.

\section{Conclusions}

Calcium aluminate cements with $\mathrm{MgAl}_{2} \mathrm{O}_{4}$ spinel are prepared with different compositions and particle sizes. The results show that the mineral phases are mainly CA, $\mathrm{CA}_{2}$ and $\mathrm{MA}$ in cement. The shape of MA particles changes from granular to octahedron as the temperature increases from $1400^{\circ} \mathrm{C}$ to $1500^{\circ} \mathrm{C}$. The distribution of MA and $\mathrm{CA} / \mathrm{CA}_{2}$ is largely influenced by MA content and particle size. The MA particles are in clusters and are distributed around the $\mathrm{CA} / \mathrm{CA}_{2}$ particles when synthesized at $1400^{\circ} \mathrm{C}$, whereas CA particles are surrounded by or interspersed with MA particles at $1500^{\circ} \mathrm{C}$.

The particle size and content of MA particles have a strong effect on the setting time and rheological properties of CMA cement. The CMA cement with higher MA content and larger particle size demonstrates longer setting 

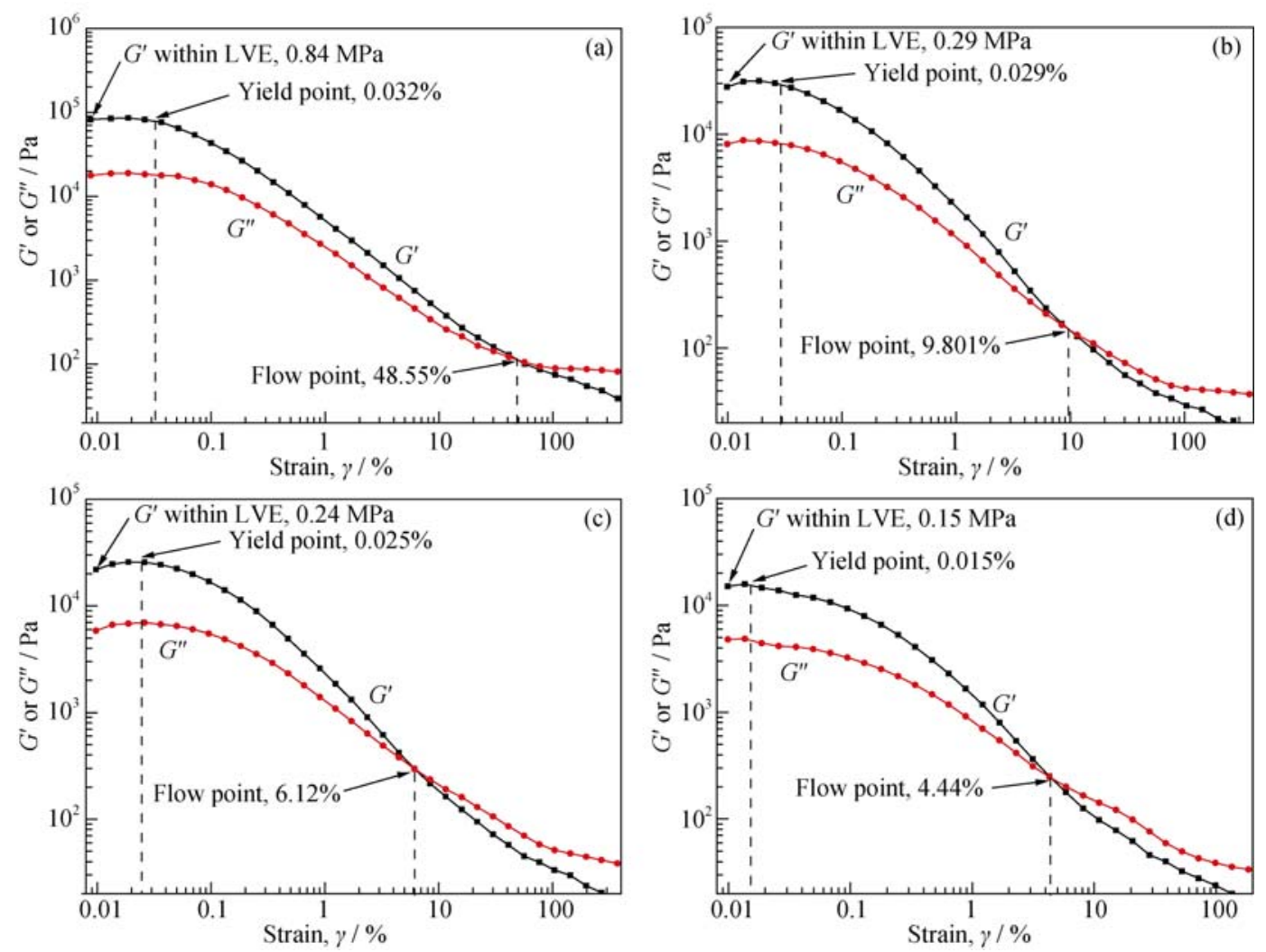

Fig. 7 Strain-sweep curves of different CMA cements

(a) Slurry for CMA cement A; (b) Slurry for CMA cement B; (c) Slurry for CMA cement C; (d) Slurry for CMA cement D

time and weaker flow behavior. On the other hand, the higher content and smaller particle size of the CA phase in CMA cement lead to a strong flocculation structure during the hydration process. Both storage modulus and flow point decrease with the increase in MA content and particle size.

\section{References:}

[1] ABO-EL-ENEIN SALAH A, ABOU-SEKKINA MORSY M, KHALIL NAGY M, et al. Microstructure and refractory properties of spinel containing castables. Ceram. Int., 2010, 36(5): 1711-1717.

[2] BRAULIO M A L, RIGAUD M, BUHR A, et al. Spinel-containing alumina-based refractory castables. Ceram. Int., 2011, 37(6): $1705-1724$.

[3] SAKO E Y, BRAULIO M A L, BRANT P O, et al. The impact of pre-formed and in situ spinel formation on the physical properties of cement-bonded high alumina refractory castables. Ceram. Int., 2010, 36(7): 2079-2085.

[4] MUKHOPADHYAY S, DAS PODDAR P K. Effect of preformed and in situ spinels on microstructure and properties of a low cement refractory castable. Ceram. Int., 2004, 30(3): 369-380.

[5] ARACELI ELISABET LAVAT, MARIA CRISTINA GRASSELLI, EUGENIA GIULIODORI LOVECCHIO. Effect of $\alpha$ and $\gamma$ polymorphs of alumina on the preparation of $\mathrm{MgAl}_{2} \mathrm{O}_{4}$-spinel- containing refractory cements. Ceram. Int., 2010, 36(1): 15-21.

[6] BRAUlio M A L, MORBioli G G, MilaneZ D H, et al. Calcium aluminate cement source evaluation for $\mathrm{Al}_{2} \mathrm{O}_{3}-\mathrm{MgO}$ refractory castables. Ceram. Int., 2011, 37(1): 215-221.

[7] ZHANG ZHI-HUI, LI NAN. Effect of polymorphism of $\mathrm{Al}_{2} \mathrm{O}_{3}$ on the synthesis of magnesium aluminate spinel. Ceram. Int., 2005, 31(4): 583-589.

[8] HAN BING-QIANG, WANG PENG, KE CHANG-MING, et al. Hydration behavior of spinel containing high alumina cement from high titania blast furnace slag. Cem. Concr. Res., 2016, 79: 257-264.

[9] SOUZA T M, LUZ A P, PAGLIOSA CARLOS, et al. Mineralizing alumina-magnesia cement-bonded castables containing magnesium borates. Ceram. Int., 2015, 41(9): 11143-11152.

[10] XIAO GUO-QING, GAO YUN-QIN, DUAN FENG. Preparation and corrosion resistance of aluminous cement containing magnesium aluminate spinel. J. Chin. Ceram. Soc., 2008, 36(8): $1172-1177$.

[11] GEHRE P, ANEZIRIS C G, VERES D, et al. Improved spinel-containing refractory castables for slagging gasifiers. $J$. Eur. Ceram. Soc., 2013, 33(6): 1077-1086.

[12] BRAULIO M A L, BITTENCOURT L R M, PANDOLFELLI V C. Selection of binders for in situ spinel refractory castables. J. Eur. 
Ceram. Soc., 2009, 29(13): 2727-2735.

[13] NANDI P, GARG A, SINGH R K, et al. Effects of cement and magnesia fines on in situ spinel formation in alumina-magnesia castable. Adv. Appl. Ceram., 2005, 104(2): 83-88.

[14] LUZ A P, BRAULIO M A L, TOMBA MARTINEZ A G, et al. Slag attack evaluation of in situ spinel-containing refractory castables via experimental tests and thermodynamic simulations. Ceram. Int., 2012, 38(2): 1497-1505.

[15] TOMBA MARTINEZ A G, LUZ A P, BRAULIO M A L, et al. CA 6 impact on the corrosion behavior of cement-bonded spinelcontaining refractory castables: an analysis based on thermodynamic simulations. Ceram. Int., 2015, 41(3): 4714-4725.

[16] LI JIN-HONG, CAI BI-YA, FENG WU-WEI, et al. Investigations on phase constitution, mechanical properties and hydration kinetics of aluminous cements containing magnesium aluminate spinel. Ceram. Int., 2013, 39(7): 8393-8400.

[17] AUVRAY JEAN-MICHEL, GAULT CHRISTIAN, HUGER MARC. Microstructural changes and evolutions of elastic properties versus temperature of alumina and alumina-magnesia refractory castables. $J$. Eur. Ceram. Soc., 2008, 28(10): 1953-1960.

[18] ZHU BO-QUAN, WANG YU-LONG, LI XIANG-CHENG. Effect of phase distribution on rheological behavior of calcium aluminate cement with built-in alumina-magnesia spinel. J. Chin. Ceram. Soc., 2014, 42: 1383-1388.

[19] STARK JOCHEN. Recent advances in the field of cement hydration and microstructure analysis. Cem. Concr. Res., 2011, 41(7): 666-678.

[20] SILVA ABILIO P, SEGADÃES ANA M, PINTO DEESY G, et al. Effect of particle size distribution and calcium aluminate cement on the rheological behaviour of all-alumina refractory castables. Powder Technol., 2016, 226: 107-113.

[21] OLIVEIRA I R, ORTEGA F S, PANDOLFELLI V C. Hydration of $\mathrm{CAC}$ cement in a castable refractory matrix containing processing additives. Ceram. Int., 2009, 35: 1545-1552.

[22] WANG YU-LONG, ZHU BO-QUAN, LI XIANG-CHENG, et al. Effect of dispersants on the hydrate morphologies of spinelcontaining calcium aluminate cement and on the properties of refractory castables. Ceram. Int., 2016, 42: 711-720.

[23] LONG BIN, BUHR ANDREAS, XU GUI-YING. Thermodynamic evaluation and properties of refractory materials for steel ladle purging plugs in the system $\mathrm{Al}_{2} \mathrm{O}_{3}-\mathrm{MgO}-\mathrm{CaO}$. Ceram. Int., 2016, 42: 11930-11940.

[24] DIAZ L A, Torrecillas R. Hot bending strength and creep behaviour at $1000-1400^{\circ} \mathrm{C}$ of high alumina refractory castables with spinel, periclase and dolomite additions. J. Eur. Ceram. Soc., 2009, 29: 53-58.

[25] ZHU BO-QUAN, SONG YA-NAN, LI XIANG-CHENG, et al. Synthesis and hydration kinetics of calcium aluminate cement with micro $\mathrm{MgAl}_{2} \mathrm{O}_{4}$ spinels. Mater. Chem. Phys., 2015, 154: 158-163.

[26] PENG JIAN-WEI, DENG DE-HUA, LIU ZAN-QUN, et al. Rheological models for fresh cement asphalt paste. Constr. Build. Mater., 2014, 71: 254-262.

[27] MEZGER THOMAS G. The Rheology Handbook, 3rd, Vincentz Network: Hannover Press, 2011, 3: 38-51.

[28] HAFIANE Y EL, SMITH A, BONNET J P, et al. Effect of a carboxylic acid on the rheological behavior of an aluminous cement paste and consequences on the properties of the hardened material. J. Eur. Ceram. Soc., 2005, 25(7): 1143-1147.

\title{
含镁铝尖晶石的铝酸钙水泥的合成与流变特性
}

\author{
付云飞，朱伯铨，李享成，陈平安 \\ (武汉科技大学 省部共建耐火材料与冶金国家重点实验室，武汉 430081)
}

\begin{abstract}
摘 要: 在 $1400^{\circ} \mathrm{C}$ 和 $1500^{\circ} \mathrm{C}$ 温度下合成了不同配比的铝酸钻水泥(CMA)。检测结果显示, 当温度升高时镁铝尖晶石的 粒径由 $5 \mu \mathrm{m}$ 生长到 $15 \mu \mathrm{m}$ 。合成温度达到 $1400^{\circ} \mathrm{C}$ 时, 镁铝尖晶石晶粒呈团簇状并分布在铝酸䥻晶粒周围; 当合成温 度升高至 $1500^{\circ} \mathrm{C}$ 时, 镁铝尖晶石晶粒穿插在铝酸钻晶粒中。另外, 随着水泥中镁铝尖晶石含量的增加, 水泥的凝结时 间延长，同时粘度下降。相应的，水泥储能模量和流动点的大小分别为 $0.15 \mathrm{MPa}$ 和 $4.44 \%$ 。提高镁铝尖晶石相的含量 或增大铝酸钙晶粒尺寸会减弱水泥水化时絮凝结构的强度。
\end{abstract}

关 键 词: 铝酸钙水泥; 镁铝尖晶石; 合成; 流变性能

中图分类号: TQ147

文献标识码: A 